\title{
Follow-up of a social skills training (SST) for juvenile delinquents: effects on reoffending
}

\author{
Trudy van der Stouwe ${ }^{1}$ (D) Jessica J. Asscher ${ }^{1,2}$ • Machteld Hoeve ${ }^{1}$. \\ Peter H. van der Laan $^{3} \cdot$ Geert Jan J. M. Stams ${ }^{1}$
}

Published online: 13 September 2018

(C) The Author(s) 2018

\section{Abstract}

Objectives To examine (1) the long-term effects on reoffending of an individual SST for juvenile delinquents in The Netherlands and (2) whether effects differ by demographic and offense history characteristics.

Methods The present study is a follow-up of a matched control study comparing posttreatment effects of $N=115$ juveniles receiving Tools4U, an SST with a parental component, to $N=108$ control group juveniles receiving treatment as usual (TAU). Analyses were conducted separately for delinquents and truants. Effects in terms of recidivism were assessed using official delinquency data after 6 and 12 months and 1.46 years after SST termination. Percentage of recidivists, number of re-arrests, and violent recidivism were outcome variables.

Results Overall, 39\% of the juveniles reoffended, and there were no differences between Tools4U and TAU on any of the selected recidivism outcomes. Additionally, demographic and delinquency characteristics and post-treatment effects did not moderate effectiveness.

Conclusions Tools $4 \mathrm{U}$ was not more effective than TAU in preventing recidivism, which may be explained by a generally low percentage of recidivists. With established treatment integrity, and a lack of well-researched effective treatment alternatives, Tools4U could still be a reasonable treatment option for adolescent onset juvenile offenders, although more research is needed to confirm this.

Keywords Effectiveness · Juvenile delinquents $\cdot$ Social skills training $\cdot$ Recidivism • Moderators

Electronic supplementary material The online version of this article (https://doi.org/10.1007/s11292-0189340-8) contains supplementary material, which is available to authorized users.

Trudy van der Stouwe

t.vanderstouwe@uva.nl

Extended author information available on the last page of the article 


\section{Follow-up of a social skills training (SST) for juvenile delinquents: effects on recidivism}

Juvenile delinquency interventions generally aim at reducing reoffending by decreasing (dynamic) risk factors that put juveniles at higher risk for delinquency. Juvenile offender social skills training (SST) is thought to reduce reoffending by targeting social skills deficits (Lipsey et al. 2010). However, there are few empirical studies showing that improving (post-treatment) dynamic risk factors leads to a reduction of reoffending (Andrews and Bonta 2010; Douglas and Skeem 2005). Furthermore, although existing research on the effectiveness of SST on related, generally broader, target populations of adolescents with emotional and behavioral disorders shows promising outcomes that could reduce reoffending (e.g., Ang and Hughes 2002; Cook et al. 2008; Maag 2006), most studies examined outcomes after a limited follow-up duration ( $<6$ months), using a waiting list or placebo control group instead of treatment as usual (TAU). The present study therefore examined whether an SST for juvenile delinquents that has been shown to be effective in changing (post-treatment) dynamic risk factors (Van der Stouwe et al. 2016) is effective in reducing long-term recidivism.

The present study is a follow-up of a recent study that examined the implementation and post-treatment effectiveness of SST Tools4U, an outpatient individual SST for juvenile delinquents imposed as a penal sanction in The Netherlands (Van der Stouwe et al. 2016). This matched control study on 223 juvenile offenders showed that Tools $4 U$ was more effective than TAU (i.e., a community service order or another behavioral training sentence) in decreasing impulsivity $(d=.31)$ and cognitive distortions $(d=.28-.41)$, and improving social information processing $(d=.42)$ as well as parenting skills (only for caretakers of girls, $d=.73$ ). However, no treatment effects were found on social problem-solving and behavioral adjustment, and Tools4U juveniles reported significantly less social acceptance $(d=-.28)$ and self-worth $(d=-.30)$ than juveniles receiving TAU.

Because $17 \%$ of the juveniles referred to Tools4U were truants, and truancy is technically not a criminal offense, we conducted the analyses on (re)offending for offenders and truants separately. In addition to investigating long-term offending outcomes, we examined the influence of gender, age, and ethnicity, because Tools4U has shown differential posttreatment effects for age and gender (Van der Stouwe et al. 2016). This is in line with previous research indicating that treatment effectiveness may differentiate between different gender, age, and ethnic groups (Huey and Polo 2008; Van der Put et al. 2013; Zahn et al. 2009). Second, we examined moderator effects for offense history characteristics, because these are important predictors of general (re)offending (Andrews and Bonta 2010; Van der Put et al. 2013) and can help determine for which (type of) offenders Tools4U is the most effective and appropriate. Finally, given the large research base showing that impulsivity, cognitive distortions, and social information processing are important risk factors for delinquency (Helmond et al. 2015b; Nas et al. 2005; Veltri et al. 2014), treatment effects on these outcomes should arguably lead to a reduction in reoffending. We tested this hypothesis by examining mediation effects of post-treatment impulsivity, hostile intent attribution, self-centering, and assuming the worst.

We hypothesize that Tools $4 \mathrm{U}$ would be more effective in reducing recidivism than TAU, in particular for girls, and juveniles under 16 years old. We would expect larger treatment effects than in previous studies, because the intervention has addressed 
several suggested causes for limited treatment effects (see, e.g., Ang and Hughes 2002; Cook et al. 2008; Gresham et al. 2004; Maag 2006). That is, Tools4U has shown to have sufficient treatment integrity (Van der Stouwe et al. 2016), is delivered individually (which would prevent deviancy training, Dishion et al. 1999), and has included parents in treatment, to ensure generalization of treatment effects to daily life and over time (Albrecht and Spanjaard 2011).

\section{Methods}

\section{Participants}

The treatment group consisted of all juveniles $(N=115)$ who received SST Tools4U in The Netherlands between May and August 2012. This treatment group was matched to a control group $(N=108)$ of juveniles with a community service order or another behavioral training order (treatment as usual, TAU) between June 2013 and February 2014. The comparison group was a subsample, derived from $N=354$ control group juveniles by means of propensity score matching based on gender, age, ethnicity, and all pre-test social skills questionnaire scales. After matching, no differences on any of the included pre-test characteristics were found, except in degree of urbanization and self-perception of behavioral adjustment (for an elaborate description, see Van der Stouwe et al. 2016 or online Appendix A).

The sample consisted of a majority of boys $(n=159,72 \%)$ with an average age of $M=15.71(S D=1.54)$, and half of the juveniles was from an ethnic minority background $(n=112,50 \%)$. Most juveniles $(35 \%, n=79)$ committed a property offense, while $23 \%(n=50)$ of the juveniles received their sentence for only truancy, and participants had committed on average .91 ( $S D=1.61)$ offenses. By separating offenders and truants, only a difference between groups in degree of urbanization remained for truants, and not for any of the other characteristics (see online Appendix B).

\section{Treatment conditions}

Juveniles in the treatment group received Tools4U, an outpatient individual SST imposed as a (penal) sanction for juveniles who have committed an offense (Albrecht and Spanjaard 2011). The - 8 to 12 weeks - weekly training is intended for delinquent juveniles (12 to 18 years) with a moderate risk of reoffending for whom lack of cognitive and social skills is related to delinquent behavior. Control group juveniles received any usual treatment other than Tools4U. The vast majority $(94 \%, n=102)$ received a community service order, and the remaining juveniles received another behavioral training sentence $(6 \%, n=6)$ with duration, training hours, and training intensity similar to Tools4U (i.e., individual aggression regulation or substance abuse training).

\section{Outcomes and measures}

Recidivism was measured through official recidivism data from the Dutch Judicial Information Service (JustID). Formal consent for requesting these data was obtained 
from the Netherlands Ministry of Security and Justice. The records were released in February 2016 and coded using the Recidivism Coding System (RCS) of the Research and Documentation Centre (Wartna et al. 2005, 2011). Recidivism was defined in terms of frequency (dichotomous variable: at least one arrest; and continuous variable: number of arrests), and violent recidivism at 6 months, 12 months, and the maximum available follow-up duration available for all juveniles, which was 1.46 years. Truancy was not included as reoffending, because it is technically not a criminal offense, and registration in the judicial system took significantly longer for truancy compared to other offenses (truancy: $M=292.72$ days, $S D=148.11$; other offenses: $M=$ 99.98 days, $S D=117.12 ; t=-14.93, p<.001)$. Judicial records could be traced for all but one control group juvenile, resulting in a control group for analysis of $n=107$ matched control group juveniles.

\section{Analytic strategy}

All (re)offending analyses were conducted for delinquents $(N=172)$ and truants $(N=50)$ separately. For offenders, we examined (violent) reoffending at a follow-up of 6 months, 12 months, and 1.46 years. Due to a limited number of (violent) offenders at the early assessment waves, analyses for truants were only conducted for general offending at the maximum follow-up time of 1.46 years, while no moderator analyses were performed for this group. The degree of urbanization was included as a covariate in all analyses, because the treatment groups differed on this variable after matching. In addition, to improve statistical power of the analyses, we included variables that are highly predictive of general recidivism (Cottle et al. 2001) as covariates in the offender analyses: the number of previous arrests and the type of index offense.

The effects for percentage recidivists and violent recidivists were examined using logistic regression analysis. The number of rearrests was examined using Poisson regression analysis. In addition, we conducted Cox regression analysis to examine the differences in survival curves between Tools4U and TAU. The covariates were added into to the model at step 1, while condition was added in the second step. A Chisquare difference test shows whether condition predicts survival length over duration to follow-up.

For the moderator analyses, the same Cox regression analyses were conducted, but the moderator and the interaction between the moderator and condition were added to the equation at 6 months, 12 months, and 1.46 years. Following this, we examined whether reoffending was moderated by the interaction condition $\times$ gender, condition $\times$ age, condition $\times$ ethnicity, condition $\times$ more than one previous offense, and condition $\times$ violent offender. In addition, we examined whether reoffending was moderated by post-treatment scores on impulsivity, attributing hostile intent, self-centering, and assuming the worst (i.e., outcomes that Tools4U has shown post-treatment effects on; Van der Stouwe et al. 2016). In addition to the post-treatment score and the interaction between post-treatment score and condition, the pre-treatment score on the outcome was added as a covariate to control for pre-treatment differences. 


\section{Results}

\section{Intervention effects}

Results of the analyses of the intervention effects on (violent) (re)offending at 6 months, 12 months, and 1.46 years post-treatment are presented in online Appendices C and D. Overall, $39 \%$ of the offenders reoffended, and $20 \%$ of the truants committed an offense within 1.46 years after treatment. Treatment condition did not predict (re)offending, violent reoffending, or the number of (re)offenses on any of the follow-up assessments. Furthermore, there were no differences in survival curves between Tools4U and TAU after 6 months $(H R=1.17, p=.67,95 \%$ Confidence Interval $[C I]=0.59,2.30), 12$ months $(H R=1.32$, $p=.31,95 \% C I=0.77,2.26$ ), and 1.46 years (delinquents: $H R=1.19, p=.50,95 \% C I=$ $0.73,1.94$, see Fig. 1; truants: $H R=.44, p=.28,95 \% C I=0.10,1.95$, see Fig. 2). Juveniles receiving Tools $4 \mathrm{U}$ did not recidivate more or less often, frequent, or violent than juveniles receiving TAU.

\section{Moderators of effectiveness}

Demographic characteristics We conducted moderator analyses to examine the influence of gender, age, and ethnicity on treatment effects. To examine age, participants were divided into a group of juveniles younger than 16 years of age $(n=95)$ and 16 years and older $(n=127)$. To investigate the influence of ethnicity on treatment effects, participants were divided into two ethnic groups: Dutch natives $(n=111)$ and juveniles with an ethnic minority background (one or both parents not born in The Netherlands, $n=111$ ).

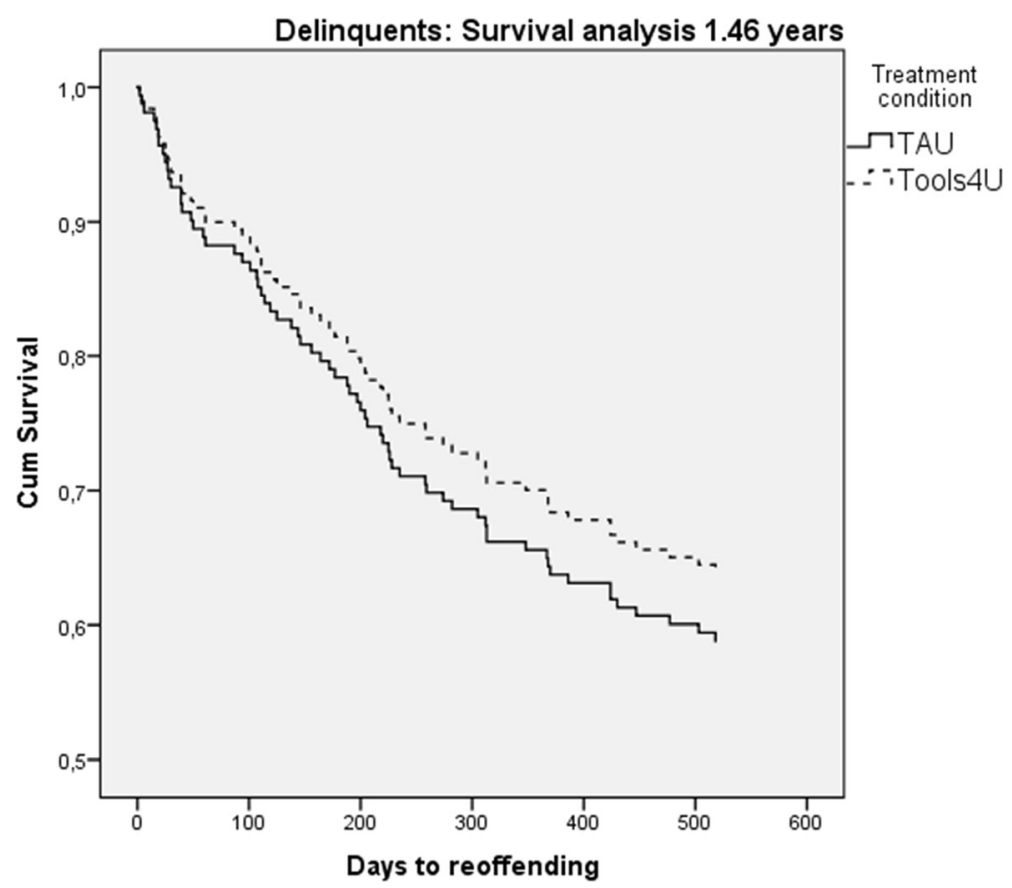

Fig. 1 Delinquents: survival curve for Tools4U and TAU separately at 1.46 years 


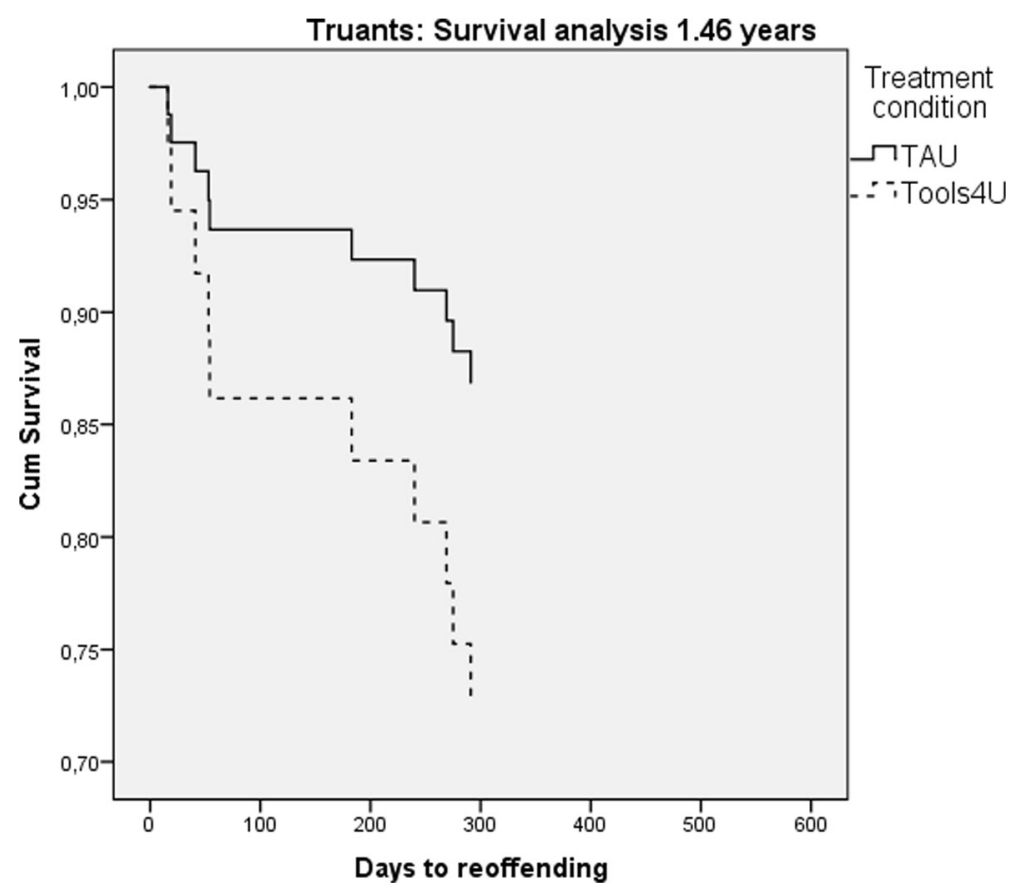

Fig. 2 Truants: survival curve for Tools $4 U$ and TAU separately at 1.46 years

No significant moderating effects were found for gender, age, or ethnicity at 6 months, 12 months, and 1.46 years (see online Appendix E). There were no differential effects of Tools4U for gender, age, and ethnic groups.

Offense history characteristics Moderator analyses were conducted to investigate the influence of being a violent offender and having committed more than one previous offense on treatment effects. Juveniles convicted for a violent offense were considered violent offenders $(n=65)$, the number of previous offenses was used to construct two groups of juveniles with one or no previous offense versus more frequent offenders $(n=55)$. There were no significant moderating effects for violent offending or having committed more than one previous offense after 6 months, 12 months, and 1.46 years (see online Appendix E).

Post-treatment skills Moderator analyses were conducted to investigate the influence of the post-treatment skills that showed treatment effects immediately after Tools4U. There were no significant moderating effects for impulsivity, attributing hostile intent, self-centering, and assuming the worst after 6 months, 12 months, and 1.46 years (see online Appendix E).

\section{Discussion}

The current study examined the effects of SST Tools4U for juvenile delinquents on recidivism based on official judicial data. We expected the small-to-medium positive 
post-treatment effects on dynamic risk factors that were found in our previous study (Van der Stouwe et al. 2016) to result in a reduction of recidivism. However, Tools4U was not more or less effective than TAU in preventing general recidivism, nor in the frequency, or severity of recidivism at 6 months, 12 months, and 1.46 years for offenders or truants. Moreover, there were no differences in effects between demographic and offender subgroups, and post-treatment effects showed no influence on reoffending.

These outcomes are in line with existing research that has found limited long-term effects of SST (Ang and Hughes 2002), and other behavioral interventions targeting delinquency, which have been implemented in The Netherlands (Asscher et al. 2014; Brugman and Bink 2011; Helmond et al. 2015a). Moreover, using a TAU control group instead of a minimal/no treatment control group (as was the case in the majority of previous studies, Ang and Hughes 2002), and conducting the study under clinically representative conditions could have limited finding treatment effects in the present study. However, the present outcomes could also indicate that (post-treatment) improvements on social skills do not generalize to less criminal behavior.

The target population may provide the best explanation for the lack of treatment effects of Tools4U. The present sample shows an overall recidivism rate of $37 \%$ after almost 1.5 years, which is similar to the national juvenile recidivism rate (i.e., $36 \%$, Wartna et al. 2012), and lower than recidivism rates in more severe target populations (49\%-79\%, see, e.g., Asscher et al. 2014; Helmond et al. 2015a, b; Wartna et al. 2012). By successfully referring moderately severe adolescent onset or adolescent limited delinquents to Tools4U (Loeber et al. 1998; Moffitt 1993), a majority of the sample would not reoffend regardless of any intervention, which decreases the chances of finding significant treatment effects. Such a floor effect could also be an explanation for the limited sustained effects of SST in previous studies (see Cook et al. 2008; Maag 2006).

Interestingly, we found no moderating effects for age, gender, ethnicity, violent offending, or frequent offending. Given that Tools4U showed post-treatment effects on positive parenting only for parents of girls, and on behavioral adjustment only for younger juveniles (Van der Stouwe et al. 2016), the lack of differential effects on recidivism depending on gender and age is unexpected. Moreover, post-treatment effects on social skills did not have the hypothesized influence on reoffending.

The results of this study need to be interpreted in light of some limitations. First, due to practical considerations, the present study could not meet the 'golden standard' of random assignment to a treatment and control condition (Farrington 2003). Therefore, some unmeasured characteristics of juveniles may have been responsible for differences in treatment effects. Second, the statistical power for the moderator analyses was only sufficient to detect moderate subgroup effects, which could result in an underestimation of the effects of demographic and offense history characteristics. Finally, by using only official judicial data to measure delinquency, we measured "the tip of the iceberg" of actual reoffending, because only a small part of offenses leads to actual registration or conviction (Farrington and Ttofi 2014). This may have limited the percentage of reoffenders, decreasing the power to find significant treatment effects.

In sum, the present study found no treatment effects for SST Tools4U in reducing recidivism in juvenile offenders. More specifically, post-treatment effects on dynamic risk factors and sufficient treatment implementation did not lead to the expected long- 
term effects on recidivism. However, the lack of treatment effects (i.e., failure to reject the null hypothesis) does not prove that Tools4U is ineffective (i.e., accept the null hypothesis, Weisburd et al. 2003), and no negative effects were found. Tools4U thereby might reach a "minimal level of program effectiveness" (Weisburd et al. 2003, p. 43), although more research is needed to confirm this. With established treatment integrity, and a lack of well-researched effective treatment alternatives, Tools4U could still be a reasonable treatment option for adolescent onset juvenile offenders.

Open Access This article is distributed under the terms of the Creative Commons Attribution 4.0 International License (http://creativecommons.org/licenses/by/4.0/), which permits unrestricted use, distribution, and reproduction in any medium, provided you give appropriate credit to the original author(s) and the source, provide a link to the Creative Commons license, and indicate if changes were made.

\section{References}

Albrecht, G., \& Spanjaard, H. (2011). Tools4U: Training cognitieve en sociale vaardigheden als taakstraf: Handleiding voor trainers [Tools4U: Training cognitive and social skills as penal santion: Manual for trainers]. Duivendrecht: PI Research.

Andrews, D. A., \& Bonta, J. (2010). Rehabilitating criminal justice policy and practice. Psychology, Public Policy, and Law, 16, 39-55. https://doi.org/10.1037/a0018362.

Ang, R. P., \& Hughes, J. N. (2002). Differential benefits of skills training with antisocial youth based on group composition: A meta-analytic investigation. School Psychology Review, 31(2), 164-185.

Asscher, J. J., Deković, M., Manders, W. A., Van der Laan, P. H., Prins, P. J. M., Van Arum, S., \& Dutch MST Cost-Effectiveness Study Group. (2014). Sustainability of the effects of multisystemic therapy for juvenile delinquents in the Netherlands: Effects on delinquency and recidivism. Journal of Experimental Criminology, 10, 227-243. https://doi.org/10.1007/s11292-013-9198-8.

Brugman, D., \& Bink, M. D. (2011). Effects of the EQUIP peer intervention program on self-serving cognitive distortions and recidivism among delinquent male adolescents. Psychology, Crime \& Law, 17, 345-358. https://doi.org/10.1080/10683160903257934.

Cook, C. R., Gresham, F. M., Kern, L., Barreras, R. B., Thornton, S., \& Crews, S. D. (2008). Social skills training for secondary students with emotional and/or behavioral disorders a review and analysis of the meta-analytic literature. Journal of Emotional and Behavioral Disorders, 16(3), 131-144. https://doi. org/10.1177/1063426608314541.

Cottle, C. C., Lee, R. J., \& Heilbrun, K. (2001). The prediction of criminal recidivism in juveniles: A metaanalysis. Criminal Justice and Behavior, 28(3), 367-394. https://doi.org/10.1177/0093854801028003005.

Dishion, T. J., McCord, J., \& Poulin, F. (1999). When interventions harm: Peer groups and problem behavior. American Psychologist, 54(9), 755-764. https://doi.org/10.1037/0003-066X.54.9.755.

Douglas, K. S., \& Skeem, J. L. (2005). Violence risk assessment: Getting specific about being dynamic. Psychology, Public Policy, and Law, 11(3), 347-383. https://doi.org/10.1037/1076-8971.11.3.347.

Farrington, D. P. (2003). A short history of randomized experiments in criminology. A meager feast. Evaluation Review, 27(3), 218-227. https://doi.org/10.1177/0193841X03027003002.

Farrington, D. P., \& Ttofi, M. M. (2014). Criminal careers in self-reports compared with official records. Criminal Behaviour and Mental Health, 24(4), 225-228. https://doi.org/10.1002/cbm.1932.

Gresham, F. M., Cook, C. R., Crews, S. D., \& Kern, L. (2004). Social skills training for children and youth with emotional and behavioral disorders: Validity considerations and future directions. Behavioral Disorders, 30(1), 32-46.

Helmond, P. E., Overbeek, G., \& Brugman, D. (2015a). An examination of program integrity and recidivism of a cognitive-behavioral program for incarcerated youth in the Netherlands. Psychology, Crime \& Law, 21(4), 330-346. https://doi.org/10.1080/1068316X.2014.989164.

Helmond, P. E., Overbeek, G., Brugman, D., \& Gibbs, J. C. (2015b). A meta-analysis on cognitive distortions and externalizing problem behavior: Associations, moderators, and treatment effectiveness. Criminal Justice and Behavior, 42(3), 245-262. https://doi.org/10.1177/0093854814552842. 
Huey, S. J., \& Polo, A. J. (2008). Evidence-based psychosocial treatments for ethnic minority youth. Journal of Clinical Child \& Adolescent Psychology, 37(1), 262-301. https://doi.org/10.1080/15374410701820174.

Lipsey, M. W., Howell, J. C., Kelly, M. R., Chapman, G., \& Carver, D. (2010). Improving the effectiveness of juvenile justice programs: A new perspective on evidence-based practice. Washington. DC: Center for Juvenile Justice Reform.

Loeber, R., Farrington, D. P., Stouthamer-Loeber, M., \& Van Kammen, W. B. (1998). Antisocial behavior and mental health problems: Explanatory factors in childhood and adolescence. Mahwah: Lawrence Erlbaum Associates.

Maag, J. W. (2006). Social skills training for students with emotional and behavioral disorders: A review of reviews. Behavioral Disorders, 32(1), 5-17.

Moffitt, T. E. (1993). Adolescence-limited and life-course-persistent antisocial behavior: A developmental taxonomy. Psychological Review, 100(4), 674. https://doi.org/10.1037/0033-295X.100.4.674.

Nas, C. N., Orobio De Castro, B., \& Koops, W. (2005). Social information processing in delinquent adolescents. Psychology, Crime \& Law, 11(4), 363-375. https://doi.org/10.1080/10683160500255307.

Van der Stouwe, T., Asscher, J. J., Hoeve, M., Van der Laan, P. H., \& Stams, G. J. J. M. (2016). Social skills training for juvenile delinquents: Post-treatment changes. Journal of Experimental Criminology, Advance Online Publication. https://doi.org/10.1007/s11292-016-9262-2.

Van der Put, C. E., Stams, G. J. J. M., Deković, M., Hoeve, M., \& Van der Laan, P. H. (2013). Ethnic differences in offense patterns and the prevalence and impact of risk factors for recidivism. International Criminal Justice Review, 23(2), 113-131. https://doi.org/10.1177/1057567713482940.

Veltri, C. O. C., Sellbom, M., Graham, J. R., Ben-Porath, Y., Forbey, J. D., \& White, R. S. (2014). Distinguishing personality psychopathology five (PSY-5) characteristics associated with violent and nonviolent juvenile delinquency. Journal of Personality Assessment, 96(2), 158-165. https://oi. org/10.1080/00223891.2013.843539.

Wartna, B. S. J., El Harbachi, S., \& Van der Laan, A. M. (2005). Jong vast: Een cijfermatig overzicht van de strafrechtelijke recidive van ex-pupillen van justitiele jeugdinrichtingen [youth in detention: Prevalence of recidivism in youth in juvenile justice institutions]. The Hague: Research and Documentation Centre.

Wartna, B. S. J., Blom, M., \& Tollenaar, N. (2011). The dutch recidivism monitor. The Hague: Research and Documentation Centre.

Wartna, B. S. J., Tollenaar, N., Blom, M., Verweij, S., Alberda, D. L., \& Essers, A. A. M. (2012). Recidivebericht 2012: Landelijke cijfers met betrekking tot de strafrechtelijke recidive van justitiabelen uit de periode 2002-2009. (Factsheet No. 2012-6). Den Haag: Wetenschappelijk Onderzoek- en Documentatiecentrum Ministerie van Veiligheid en Justitie.

Weisburd, D., Lum, C. M., \& Yang, S. (2003). When can we conclude that treatments or programs "Don't work"? The Annals of the American Academy of Political and Social Science, 587(1), 31-48. https://doi. org/10.1177/0002716202250782.

Zahn, M. A., Day, J. C., Mihalic, S. F., \& Tichavsky, L. (2009). Determining what works for girls in the juvenile justice system a summary of evaluation evidence. Crime \& Delinquency, 55(2), 266-293. https://doi.org/10.1177/0011128708330649.

Trudy van der Stouwe is a $\mathrm{PhD}$ Candidate of Forensic Child and Youth Care Sciences at the Research Institute Child Development and Education of the University of Amsterdam, The Netherlands. She graduated in Forensic Child and Youth Care Sciences. Her research interests include social skills training, effectiveness of juvenile offender interventions, and the effects of (combat) sports on behavioral problems.

Jessica J. Asscher combines her associate professorship at the Department of Forensic Child and Youth Care Sciences at the University of Amsterdam with a full professorship Forensic Child and Youth Care Sciences at Utrecht University, The Netherlands. She graduated in Developmental Psychology. She is project leader of various resarch projects focussing on the effectiveness of forensic youth care (e.g., New Perspectives upon Return, and Tools4U social skills training for juvenile offenders). Furthermore, she is projectleader of a randomized Controlled Trial examining the effectiveness of Family Group Conferencing in Youth Care, the effectiveness of Dutch Cell Dogs and a project examining the gender sensitivity of treatment in JeugdzorgPlus instellingen. Her main research interests are effectiveness of prevention and intervention programmes in (forensic) youth care, parenting support programs, Risk and protective factors for) development of parentingand child behavior problems, Delinquency and antisocial behavior, and Parent - child dyadic interaction.

Machteld Hoeve is Associate Professor of Forensic Child and Youth Care Sciences at the Research Institute Child Development and Education of the University of Amsterdam, The Netherlands. She is graduated in 
Clinical Psychology and received her Ph.D. at the Radboud University Nijmegen, the Netherlands. She was a Marie Curie visiting research fellow at the Division of Child and Adolescent Psychiatry of Columbia University (2011-2012). Her research focuses on the development of juvenile delinquency, in particular risk factors of juvenile delinquency such as family factors, and mental health problems in juvenile justice youth.

Peter H. van der Laan is Professor of Probation and Parole at the Vrije Universiteit Amsterdam, The Netherlands, and is Senior Researcher at the Netherlands Institute for the Study of Crime and Law enforcement (NSCR), Amsterdam. His research interests include child protection, juvenile delinquency, (youth) probation and (youth) criminal law, with a special focus on implementation and effectiveness of criminal justice interventions.

Geert Jan J.M. Stams is Professor of Forensic Child and Youth Care Sciences at the University of Amsterdam, The Netherlands. He has conducted meta-analyses, longitudinal research and intervention studies in the area of socio-emotional and moral development. His interests include parent-child relationship quality, juvenile delinquency, developmental psychopathology, and effectiveness of youth care.

\section{Affiliations}

\section{Trudy van der Stouwe ${ }^{1}$ - Jessica J. Asscher ${ }^{1,2}$ • Machteld Hoeve ${ }^{1}$ - Peter H. van der Laan $^{3} \cdot$ Geert Jan J. M. Stams ${ }^{1}$}

1 Forensic Child and Youth Care Sciences, University of Amsterdam, Amsterdam, The Netherlands

2 Forensic Child and Youth Care Sciences, Utrecht University, Utrecht, The Netherlands

3 Criminology, Vrije Universiteit Amsterdam and Netherlands Institute for the Study of Crime and Law Enforcement, Amsterdam, The Netherlands 